\title{
The Role Of The Academic Portfolio In Documenting Faculty Development
}

Genevieve Pinto Zipp, Seton Hall University, USA

Susan Simpkins, UT Southwestern Medical Center, USA

\begin{abstract}
The academic portfolio provides a means for faculty to organize, present and reflect on their accomplishments in the areas of teaching, scholarship and service. Since the portfolio represents faculty accomplishments in these key areas it may be used to support an application for promotion, tenure or merit reviews. Given this, it is important to identify faculty's knowledge and perspectives on the structure and utility of the academic portfolio. Surveys were sent to faculty at Seton Hall University to gather information on what faculty know about academic portfolios and whether portfolios should be used for promotion/tenure or merit reviews. Results indicate that faculty understand the characteristics and organization of a portfolio, but are not certain about whether portfolios should be used for personnel decisions. The lack of objective criteria for evaluating portfolios may be a factor underlying this perspective. Further research using a larger sample is warranted.
\end{abstract}

Keywords: portfolio, faculty reviews, scholarship

\section{INTRODUCTION}

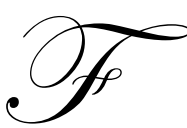

aculty roles within an academic institution traditionally include teaching, scholarship and service. As faculty we are faced with the ongoing responsibility of documenting our progress and displaying our outcomes in each of these areas. The academic portfolio as described by Peter Seldin (2009), offers a conceptual framework that can be used by faculty to record, share and reflect upon accomplishments. The framework is a flexible structure that allows for individuality in both content and organization, in the three general areas represented in most academic portfolios.

Typically, the portfolio includes material that reflects one's own philosophy of teaching, teaching goals, mechanisms to achieve those goals, and curricular material with revisions when appropriate. The second part of the teaching portfolio typically includes materials from others such as colleague statements, student and alumni reviews, honors and recognitions. The final section of the teaching portfolio is outcome driven and documents teaching methods and student learning products. The products document student's outcomes, as well as the mentorship provided by the professor in fostering students learning and growth. The array of documentation presented in the three sections of the academic portfolio offer insight into the depth of the professor's teaching and scholarship. One of the key features of the academic portfolio is that the individual parts of the portfolio support the whole. Therefore, when constructing a portfolio the professor must ensure that the teaching performance depicted is a fair, non biased, representative picture of the professor's accomplishments.

The portfolio, unlike a professor's curriculum vitae or student ratings, addresses the professor's professional priorities, strengths and weaknesses. Via the portfolio the professor can offer insight into the journey taken and address issues that may have impeded the journey. The professor's reflection on his or her strengths and weakness, and the strategies that were or may be taken, allows for an ongoing self-assessment and development of the professor as a true scholar. Finally, the portfolio enables professors to share their perspectives on the significance of their work and present the varied documentation that supports their accomplishments. 
The challenge for faculty is to ensure that a balance exists within their portfolio with regard to the quality and significance of the work they select to highlight. The portfolio should support a comprehensive examination of the faculty members teaching, scholarship and service. Providing information on what a professor does and why he does it along with its significance offers great insight into the professor's roles and effectiveness in the academic environment. Given the portfolio's comprehensive and integrated presentation of a professors teaching, scholarship and service the document may serve as a vehicle for implementing equitable faculty reviews including those associated with promotion and tenure. To date, literature on the use of the portfolio as a mechanism for faculty reviews is limited to antidotal information or case-based scenarios.

Clearly, the portfolio is a developing document that reflects the professor's professional journey. The portfolio offers the professor a repository not only for their professional outcomes but their reflections and perspectives on teaching, scholarship and service. But what are faculty perceptions on portfolios, specifically with regard to development, practicality and relevance? The question arises as to whether faculty view the academic portfolio as a meaningful document that can be a useful tool in the review process and consequently career advancement. Based upon this issue and the increasing utilization of portfolios a survey was developed to assess faculty's knowledge and perceptions of portfolios including their usefulness in faculty reviews and assessments. The survey addressed three specific topics; 1. What is a portfolio?, 2. What is included in a portfolio?, and 3. How should a portfolio be used in an academic setting? By gaining an initial understanding of what faculty know about portfolios and their application in the academic environment the ground work for further development of portfolios and their application may emerge.

\section{METHODS}

\section{Subjects}

All current full-time faculty (350) of the Seton Hall University community were invited to participate in the study by completing an on-line survey. A total of 25 completed responses were received along with 23 incomplete responses that were not included into the survey analysis resulting in a $7 \%$ survey response rate.

\section{Procedures}

All full-time faculty of SHU received an email with a link to a web-based survey. The survey was completed solely on that faculty member's computer, at whatever location they preferred. The survey host (ASSET, SHU) stored the survey responses until they were downloaded by the researchers into a spreadsheet. The survey included 27 questions: 16 forced response using a 1-5 Likert scale, three yes/no, one open-ended, and seven demographic questions. While this survey was not been validated, it was created specifically to gather information on faculty perceptions of this topic.

\section{STUDY DESIGN}

A quantitative, exploratory, prospective survey design was used to address the research question. The dependent variables were the survey responses regarding knowledge and perceptions, and the independent variable was content and utilization of the portfolio. Survey data analysis included the generation of percent agreement scores.

\section{RESULTS}

Table 1 provides a profile of the survey respondent's which reflect the larger population of the faculty within this university.

Survey questions were grouped to determine:

1. What faculty thought about Portfolios?

2. What content is included in a Portfolio?

3. Should the Portfolio be used for decisions about tenure/promotion and merit reviews? 
Tables 2, 3, and 4 details responses in percentages across a Likert scale from strongly agree (5) to strongly disagree (1). Additionally, means and standard deviation scores for each question are provided. Based upon this data more than half the respondents had experience developing an academic portfolio. Most faculty understood the nature of an academic portfolio as defined by Seldin and what information a portfolio usually contains. However, faculty presented mixed feelings about whether academic portfolios should be used to determine promotion/tenure or compensation, with the largest percentage of respondent's choosing the neutral category.

Table 1: Description of the Survey Respondents Profile

\begin{tabular}{|c|c|c|}
\hline Respondents Profile & Number & Percentage \\
\hline Gender & & \\
Male & 8 & $32 \%$ \\
\hline Female & 17 & $17 \%$ \\
\hline Academic Rank & & \\
Professor & 2 & $20 \%$ \\
\hline Assoc Professor & 10 & $40 \%$ \\
\hline Assist Professor & 5 & $4 \%$ \\
\hline Instructor & 1 & $16 \%$ \\
\hline Other & 4 & \\
\hline Years Teaching & & $16 \%$ \\
\hline o-6 & 4 & $12 \%$ \\
\hline $7-10$ & 3 & $12 \%$ \\
\hline $11-15$ & 3 & $16 \%$ \\
\hline $16-20$ & 4 & $44 \%$ \\
\hline$>20$ & 11 & \\
\hline Level & & $80 \%$ \\
Undergraduate & & $20 \%$ \\
\hline Yes & 20 & \\
\hline No & 5 & $32 \%$ \\
\hline Graduate & 17 & \\
Yes & 8 & $32 \%$ \\
\hline No & & \\
\hline Administrative Role & 8 & \\
Yes & 17 & \\
No & & \\
\hline
\end{tabular}

Table 2: Respondents' Responses to "What do Faculty Think About Academic Portfolios?"

\begin{tabular}{|c|c|c|c|c|c|c|}
\hline Questions & SD & D & $\mathbf{N}$ & A SA & Avg & SD \\
\hline $\begin{array}{l}\text { I view the academic portfolio as an } \\
\text { opportunity to share scholarly } \\
\text { accomplishments. }\end{array}$ & $0 \%$ & $4 \%$ & $28 \%$ & $52 \%$ & 3.8 & .76 \\
\hline $\begin{array}{l}\text { The academic portfolio provides a } \\
\text { repository for faculty member's } \\
\text { achievements. }\end{array}$ & o\% & $8 \%$ & $8 \%$ & $52 \% \quad 32 \%$ & 4.08 & .86 \\
\hline $\begin{array}{l}\text { The academic portfolio is primarily used to } \\
\text { improve ones teaching, research and } \\
\text { service performance. }\end{array}$ & $8 \%$ & $12 \%$ & $40 \%$ & $36 \% \quad 4 \%$ & 3.16 & .98 \\
\hline $\begin{array}{l}\text { The academic portfolio provides for } \\
\text { reflection on ones teaching, research and } \\
\text { services. }\end{array}$ & $8 \%$ & $8 \%$ & $16 \%$ & $56 \% \quad 12 \%$ & 3.56 & 1.1 \\
\hline $\begin{array}{l}\text { The academic portfolio is the same as } \\
\text { presenting ones work using a c.v. }\end{array}$ & $12 \%$ & $44 \%$ & $24 \%$ & $20 \% \quad 0 \%$ & 2.52 & .96 \\
\hline $\begin{array}{l}\text { The academic portfolio should be } \\
\text { structured and used in a standard format } \\
\text { for all. }\end{array}$ & $8 \%$ & $24 \%$ & $28 \%$ & $20 \% \quad 4 \%$ & 3.16 & 1.2 \\
\hline
\end{tabular}


Table 3: Respondents' Responses to "What Information is Contained in Academic Portfolios?"

\begin{tabular}{|c|c|c|c|c|c|c|c|}
\hline Questions & SD & $\mathbf{D}$ & $\mathbf{N}$ & $\mathbf{A}$ & SA & Avg & SD \\
\hline $\begin{array}{l}\text { I believe that the academic portfolio } \\
\text { provides an opportunity to document } \\
\text { professional goals and objectives. }\end{array}$ & $0 \%$ & $4 \%$ & $32 \%$ & $48 \%$ & $16 \%$ & 3.76 & .77 \\
\hline $\begin{array}{l}\text { I believe that the academic portfolio } \\
\text { provides a medium to document service } \\
\text { accomplishments }\end{array}$ & o\% & O\% & $20 \%$ & $52 \%$ & $28 \%$ & 4.08 & .70 \\
\hline $\begin{array}{l}\text { The academic portfolio provides a } \\
\text { medium for faculty to discuss both } \\
\text { strengths and weaknesses in the areas of } \\
\text { teaching, service and research. }\end{array}$ & $4 \%$ & $8 \%$ & $28 \%$ & $44 \%$ & $16 \%$ & 3.6 & 1.0 \\
\hline $\begin{array}{l}\text { The academic portfolio should not solely } \\
\text { focus on faculty member's } \\
\text { accomplishments but should address their } \\
\text { skills, abilities, attitudes and philosophies } \\
\text { regarding teaching. }\end{array}$ & o\% & $8 \%$ & $20 \%$ & $48 \%$ & $24 \%$ & 3.88 & .88 \\
\hline $\begin{array}{l}\text { The academic portfolio should be rich in } \\
\text { evidence-based information. }\end{array}$ & o\% & $4 \%$ & $24 \%$ & $44 \%$ & $28 \%$ & 3.96 & .84 \\
\hline
\end{tabular}

\section{Table 4: Respondents' Response to "Do Faculty Think Academic Portfolios Should be Used for Decisions on Promotion/Tenure or Merit Increases?"}

\begin{tabular}{|c|c|c|c|c|c|c|c|}
\hline Questions & SD & $\mathbf{D}$ & $\mathbf{N}$ & $\mathbf{A}$ & SA & Avg & SD \\
\hline $\begin{array}{l}\text { The academic portfolio provides } \\
\text { quantitative data that can be used to } \\
\text { assess qualifications for tenure and } \\
\text { promotion. }\end{array}$ & $8 \%$ & $8 \%$ & $16 \%$ & $48 \%$ & $20 \%$ & 3.64 & 1.15 \\
\hline $\begin{array}{l}\text { The academic portfolio should not be } \\
\text { used as a mechanism for tenure and/or } \\
\text { promotion. }\end{array}$ & $4 \%$ & $48 \%$ & $36 \%$ & o\% & $12 \%$ & 2.68 & 1.02 \\
\hline $\begin{array}{l}\text { The academic portfolio provides } \\
\text { quantitative data that can be used for } \\
\text { merit consideration. }\end{array}$ & $8 \%$ & $8 \%$ & $28 \%$ & $10 \%$ & $4 \%$ & 3.48 & 1.12 \\
\hline $\begin{array}{l}\text { The academic portfolio should not be } \\
\text { used for personnel decisions (such as } \\
\text { tenure, promotion, merit pay). }\end{array}$ & $12 \%$ & $32 \%$ & $44 \%$ & $4 \%$ & $8 \%$ & 2.64 & 1.03 \\
\hline
\end{tabular}

\section{DISCUSSION/CONCLUSION}

This data indicate that faculty positively view academic portfolios as a reflective repository of evidenced based support for their accomplishments in the areas of teaching, scholarship and service, as well as their skills, abilities, attitudes and philosophies regarding teaching. However, the use of portfolios for decisions on promotion/tenure or merit increases requires further investigation, specifically with regard to how the portfolio is used, by whom and when. 
Faculty's concerns about using portfolios for personnel decisions may center on the lack of objective criteria for scoring, ranking or grading accomplishments, abilities or development based on the contents of a portfolio. Portfolios by nature are not criterion-based, nor do they specify a consistent structure for presenting faculty accomplishments and reflections. Therefore, if portfolios are going to be used as a mechanism for promotion/tenure or merit reviews either the philosophical underpinnings of portfolio development needs to be modified, or a mechanism for effectively evaluating a portfolio must be developed and then tested for validity and reliability. Until a sound mechanism is available to evaluate the depth of material presented in a portfolio, faculty and administrators must exercise caution when using the portfolio for purposes other than those suggested by Peter Seldin (2009).

\section{STUDY LIMITATIONS}

As with any survey bias is always a concern. This study's small $\mathrm{n}$ and limited distribution (faculty from one university) reduces generalizability. Future research efforts should be directed at examining this topic across a range of universities.

\section{AUTHOR INFORMATION}

Dr. Pinto Zipp is Associate Professor and Chair of the Department of Graduate Programs in Health Sciences at Seton Hall University. She received her EdD from Teachers College Columbia University in 1996. She currently teaches management of neuromuscular problems in the Doctor of Physical Therapy program. Her research interests focus on, a) effects of performing dual tasks on walking performance and postural sway in children and adults, and b) curriculum design issues including the use of mind mapping and video based cases in professional education for the promotion of clinical decision making skills.

Susan Simpkins is an associate professor in the Department of Physical Therapy at the University of Texas Southwestern Medical Center. She received her EdD from Teachers College Columbia University in 1999. She currently teaches pediatric patient/client management, neuromuscular patient/client management and tests and measures. Her research interests include the development of postural control and mobility in children with and without developmental disabilities and the use of active learning strategies in the classroom.

\section{REFERENCES}

1. Austin, A.E. \& Baldwin, RG. (1991). Faculty collaboration: Enhancing the quality of scholarship and teaching. ASHE-ERIC Higher Education Report No. 7.

2. Boyer, E.L. (1990). Scholarship reconsidered: Priorities of the professoriate. San Francisco: Jossey-Bass.

3. Brookfield, S.D. (1990). The Skillful Teacher. San Francisco, CA: Jossey-Bass Publishers.

4. Brookfield, S.D. and S. Preskill (1999). Discussion as a Way of Teaching. San Francisco, CA: Jossey-Bass Publishers.

5. $\quad$ Forrest, S.P., \& Peterson, T.O. (2006). It's Called Andragogy. Academy of Management \& Education, 5(1): 119-121.

6. Pinto Zipp, G., \& Olson, V. (2008). Infusing the Mentorship Model of Education for the Promotion of Critical Thinking in Doctoral Education. Journal of College Teaching \& Learning, 5(9): 9-16.

7. Seldin, P. (2009). The Teaching Portfolio. Bolton, MA: Anker Publishing Co.

8. Weimer, M. (2002). Learner-Centered Teaching. San Francisco, CA: Jossey-Bass Publishers. 
NOTES 